\title{
EFFECT OF EUGENIA JAMBOLANA ON NUMBER OF INFLAMMATORY CELLS IN GINGIVITIS IN ALBINO RATS.
}

1. M.Phil (Oral Biology) Assistant Professor Department of Oral Biology Aviecenna Medical Dental College, Lahore.

2. BDS, M.Phil (Oral Biology) Assistant Professor Department of Oral Biology de'Montmorency College of Dentistry, Lahore.

3. BDS, FCPS (Orthodontics) Professor Department of Orthodontics Avicenna Medical and Dental College, Lahore.

4. BDS, MSc (Oral Pathology), FICD Associate Professor Department of Oral Pathology Avicenna Medical and Dental College, Lahore.

5. BDS, MSc (DPH)

Assistant Professor Department of Community and Preventive Dentistry Avicenna Medical and Dental College, Lahore.

6. BDS, MCPS (Oral Surgery) Assistant Professor

Department of Oral and Maxillofacia Surgery

Avicenna Medical and Dental College, Lahore.

Correspondence Address: Dr. Sana Chaudhry

68-J, Street-1, Ex-Park View, Phase-8, DHA, Lahore. sanajawad.ch@gmail.com

Article received on: 23/11/2018

Accepted for publication: 25/06/2019

\section{INTRODUCTION}

Oral cavity is the part of mouth lies posterior to the gums and teeth, bounded above by soft and hard palate, below by inner side of mandible and tongue. The oral mucosa is divided into three main types according to their primary function; $1^{\text {st }}$ is masticatory mucosa, $2^{\text {nd }}$ is lining mucosa and $3^{\text {rd }}$ is specialized mucosa. Masticatory mucosa is present on hard palate, on the gums and dorsum of the tongue. Specialized mucosa is present on the dorsal surface of tongue which contains taste buds on the lingual papilla. The lining mucosa is found approximately $60 \%$ of the area in the oral cavity including the labial mucosa lining inside of
Sana Chaudhry ${ }^{1}$, Amna Amanat ${ }^{2}$, Nadia Bhutta ${ }^{3}$, Muhammad Behzad Salahuddin ${ }^{4}$, Muhammad Bilal Arshad ${ }^{5}$, Nasrullah Khan ${ }^{6}$

A RTRCT... Objectives: This study was conducted to study the effect of Eugenia jambolana 列

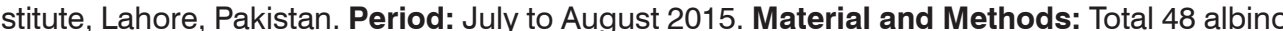
$50.00 \pm 1.414$ in group 1B. In group 1C, the neutrophils count was $27.50 \pm 1.915$, eosinophil count was $5.00 \pm 0.816$. On day 4 , in group- $2 \mathrm{~B}$, no eosinophils were seen. Lymphocytes was $9.75 \pm 1.708$, neutrophils was $6.50 \pm 1.219$ and macrophages was $3.25 \pm 1.258$. In group $2 \mathrm{C}$ $9.00 \pm 1.155$, neutrophil count was $4.00 \pm 1.414$ and macrophage count was $1.25 \pm 0.050$. On day 10 , lymphocytes, plasma cells, macrophages and few neutrophils were seen. In group3B, macrophages with large nucleus $3.25 \pm 0.95$ lymphocytes $1.25 \pm 0.500$ and few neutrophils $1.75 \pm 0.500$ and neutrophils $1.25 \pm 0.500$. On day 20 , very few lymphocytes $1.75 \pm 0.500$ and

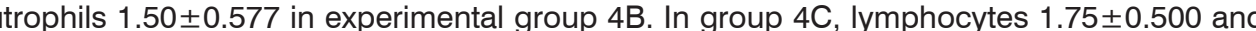
. $1.50 \pm 0.577$ were present, no evidence of macrophages and eosinophils in group B healing of gingivitis. The contents in Eugenia jambolana have an anti-inflammatory action on Key words: $\quad$ Buccal Mucosa, Eugenia Jambolana, Gingivitis, Healing. 
the periodontal tissues supporting the gums, the periodontal ligaments and the alveolar bone. Inflamed condition of gingiva is called gingivitis. ${ }^{3}$ When plaque accumulates around gingival margin, inflammation begins within gingival connective tissue and epithelium. Within 3 to 4 days connective tissue destruction starts, $70 \%$ collagen lost. Plaque is a yellowish sticky material made up of bacteria, mucus and food debris that deposits on the exposed parts of the teeth. Plaque deposition is one of the main causes of tooth decay.

Gingivitis initially affects the gums. Sign and symptoms include: painful or tender gums, swelling, softness, dusky red color, bleeding after brushing or flossing teeth. General illness, age, medication, poor dental hygiene, hormonal changes occurs in pregnancy increase the sensitivity of the gums, uncontrolled diabetes, misaligned teeth, rough edges of fillings and illfitting or dental mouth appliances such as braces, dentures, bridges and crowns when become unclean also raise the risk of gingivitis. ${ }^{4}$ Systemic diseases linked to periodontal disease include: renal, hepatic, pulmonary and cardiac diseases; osteoporosis, adverse pregnancy effects, and diabetes mellitus.

The inflamed gums have a "puffy" or "rolled" margin, with swollen and mushy appearance. Epithelial thickness increases with elongated papillae in gingival overgrowth and fibrosis occurs in the lamina propria with increased number of fibroblasts. The thickness is 5 to 10 times greater than normal gingival. ${ }^{5}$

The clinical picture of chronic gingivitis is indistinct and patients have no complaints of pain. So most patients remain unaware and are not diagnosed

\begin{tabular}{|l|c|c|c|}
\hline \multicolumn{1}{|c|}{ Categories } & \multicolumn{2}{c|}{ Histopathology, $\mathbf{n}(\%)$} \\
\hline Unsatisfactory & FNAC, $\mathbf{n ~ ( \% )}$ & Benign & Malignant \\
\hline Benign & $7(9 \%)$ & & $1(1 \%)$ \\
\hline Atypia/follicular lesion of undetermined significance & $57(71 \%)$ & $56(70 \%)$ & $1(1 \%)$ \\
\hline Suspicious for follicular neoplasm & $3(4 \%)$ & $2(3 \%)$ & $2(3 \%)$ \\
\hline Suspicious for malignancy & $8(10 \%)$ & $6(7 \%)$ & $2(3 \%)$ \\
\hline Malignant & $3(4 \%)$ & $1(1 \%)$ & $2(2 \%)$ \\
\hline Total & $2(2 \%)$ & 0 & $8(10 \%)$ \\
\hline
\end{tabular}

Table-I. Cytologic and histologic correlation according to Bethesda system.

by the dental surgeons. Spontaneous bleeding in chronic gingivitis is rare. Actually when the gingival margins touch by a sharp instrument, gingival connective tissue starts bleeding shows that the changes in the epithelium and the vascular transfigurements are quite obvious.

There are four stages of gingivitis. In the initial lesion, the initial changes occur after 2-4 days of plaque accumulation. ${ }^{6}$ Vascular changes include arteriolar dilation, capillaries and venules of dentogingivial plexus also dilate. Blood flow and gingival crevicular fluid increases, leukocytes (PMN) are predominant in connective tissue, junctional epithelium and gingival sulcus. In early lesion, changes occur within 4-7 days. ${ }^{7}$ Erythema occurs and increased formation of capillary loops between rete pegs and bleeding on probing is seen. Lymphocytes and PMN are predominant. $70 \%$ of collagen is destroyed. In established lesion, gingiva gives bluish hues, blood flow becomes sluggish. Extravasation of RBC into connective tissue, causes continuous collagen loss as inflammatory cells infiltrates increases within 2-4 weeks after accumulation of plaque accumulation, gingivitis established. ${ }^{8}$ In advanced lesion, more fiber damage occurs, sulcus depth increases due to the apical migration of junctional epithelium from cementoenamel junction. Plasma cells are prominent.

For treatment of gingivitis, the goal is to reduce inflammation. Recommended treatment includes brushing, flossing and antibacterial mouth rinses or other aids. Any other related illnesses or conditions such as oral ulcers, diabetes, renal, cardiac problems should be treated. Early stages of gingivitis may regress with proper oral hygiene, whereas the advanced forms of gingival inflammation may not heal without specific dental Histopathology, $\mathrm{n}(\%)$ 


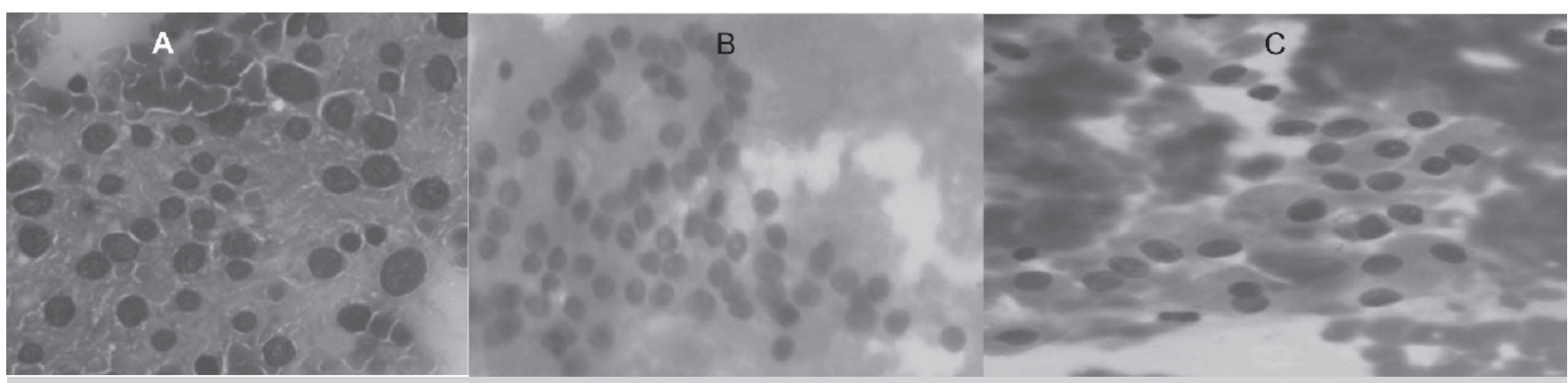

Image-A. Showing nuclear enlargement and architectural atypia, atypia of undetermined significance (AUS) was given (H\&Ex40). B. suspicious nuclear grooves and occasional pseudo inclusions, AUS is the proper diagnosis (H\&Ex40). C. Hurthle cell change Follicular neoplasm / Hurthle cell neoplasm (FN/Hurthle cell neoplasm) is the correct diagnosis (H\&Ex40).

\begin{tabular}{|c|c|c|c|c|c|}
\hline Cytological & Cases no & $\begin{array}{l}\text { Histological } \\
\text { Diagnosis }\end{array}$ & & Frequency & PPV \\
\hline \multirow[t]{2}{*}{$\begin{array}{l}\text { Bethesda } 3 \\
\text { (AUS) }\end{array}$} & 3 & Benign & $\begin{array}{l}\text { Multinodular hyperplasia } \\
\text { Hashimoto thyroiditis }\end{array}$ & $\begin{array}{l}1 \\
1\end{array}$ & \\
\hline & & Malignant & $\begin{array}{l}\text { Follicular variant of papillary } \\
\text { carcinoma }\end{array}$ & 1 & $33.3 \%$ \\
\hline $\begin{array}{l}\text { Bethesda } 4 \\
\text { (FN) }\end{array}$ & 8 & $\begin{array}{l}\text { Benign } \\
\text { Malignant }\end{array}$ & $\begin{array}{l}\text { Adenomatous hyperplasia } \\
\text { Follicular adenoma } \\
\text { Hurthle cell adenoma } \\
\text { Hashimoto thyroiditis } \\
\text { Follicular carcinoma } \\
\text { Follicular variant of papillary } \\
\text { carcinoma }\end{array}$ & $\begin{array}{l}1 \\
3 \\
1 \\
1 \\
1 \\
1\end{array}$ & $25 \%$ \\
\hline $\begin{array}{l}\text { Bethesda } 5 \\
\text { (Suspicious for } \\
\text { malignancy) }\end{array}$ & 3 & $\begin{array}{l}\text { Benign } \\
\text { Malignant }\end{array}$ & $\begin{array}{l}\text { Hashimoto thyroiditis } \\
\text { Papillary carcinoma }\end{array}$ & $\begin{array}{l}1 \\
2\end{array}$ & $66.6 \%$ \\
\hline Total & 14 & & & & $35.71 \%$ \\
\hline
\end{tabular}

Table-II. Cytologic and histologic correlation of atypical cases with PPV according to the Bethesda system $(n=14)$

treatment. ${ }^{9}$ Honey has a therapeutic effect in the treatment of gingivitis and periodontitis. There are many different types of tooth pastes available such as tooth pastes for sensitive teeth, tooth paste with flouride, bleaching tooth pastes, whitening tooth pastes. Toothpastes with triclosan and copolymer combination reduce dental plaque and symptoms of gingivitis. Dentifrices such as stannous fluoride significantly reduce gingival bleeding during gingivitis.

Eugenia jambolana is a common, large evergreen tree of the Subcontinent. Syzygium cumini linn is another scientific name of Eugenia Jambolana, belongs to the myrtaecea family. It is commonly known as 'Jamun' in Urdu language. Other names used frequently are java plum, black plum, Jambu,
Jamun, Jambul, Indian blackberry, doowet, faux pistachier, etc. It grows naturally in tropical and subtropical zones. Eugenia Jambolana tree reach upto30 meters height and its life is about 100 years. The bark is rough and colour is grey. The juice is carminative, diuretic and gives a soothing effect on digestive system. Sauces and beverages are prepared from the juice of ripe fruit. Churan is a form of digestive powder made from the dried powder of fruit with salt. The bark, flowers and seeds of Eugenia Jamboalana have hypoglycemic property used for the treatment of diabetes. Fruits and especially leaves juices were recommended for treating dysentery and gingivitis. ${ }^{10}$

There are two main types of Eugenia jambolana 
in subcontinent: (1) Ra Jaman and (2) Kaatha. The main cultivars between named cultivators are 'Early Wild', 'Late Wild' and 'Pharenda'; and the secondary ones are 'Small Jaman' and 'Dabka. In Java, Djoowet kreekil is the small form of the fruit; although the Djoowet booten is the seedless form of the fruit. In south areas of Malaya, leaves and flower clusters are small. In North, the type called 'Krian Duat' has different features. Leaves are large, thicker and inner side of bark is red. ${ }^{11}$

Fruits which have flesh of purple colour show more astringency as compared to the fruits with white-flesh. The leaves possesses antibacterial property are used for strengthening the teeth and gums. The fruit and seeds of Eugenia jambolana are sour, acrid, sweet, have tonic and cooling effects, and are used in treating diabetes mellitus, diarrhoeal problems and ringworm infections. The bark is sour, astringent, sweet, diuretic, digestive and antihelmintic. Research has shown that it has significant hypoglycemic action in both urine and blood.

\section{MATERIALS AND METHODS}

An experimental animal study was conducted at Experimental Research Laboratory of Post Graduate Medical Institute Lahore to study histological changes in the buccal side of the gingival mucosa of $1^{\text {st }}$ right maxillary molar of adult albino rats on $3^{\text {rd }}, 4^{\text {th }}, 10^{\text {th }}$ and $20^{\text {th }}$ day after inducing gingivitis in the adult albino rats. Adult animals of weight $200-250 \mathrm{gm}$ were chosen. Adult rats of both sexes were used in this study. The reagent used in this study was Eugenia Jambolana known as Jamun. The study protocol was approved by the Advanced Studies and Research Board of University of Health Sciences, Lahore and Ethical Committee of Postgraduate Medical Institute, Lahore.

\section{PROCEDURE}

Forty eight adult albino rats 55-60 days old, weighing (200-250g) were procured from National Institute of Health Islamabad. They were individually housed in a climate controlled environment and maintained on normal food and water. All animals used in this study were handled with the international, natural and institutional guidelines for care and use of laboratory animals in biomedical research as promulgated by the Canadian Council of Animal Care (1984). They were housed in cages with wire bar lids used to hold the water bottle and feed to prevent contamination with urine or feces. Animals were placed in their respective cages which were labeled by tags. Bedding was placed directly into the cage to allow the absorption of the urine. They were kept in well ventilated room at ambient temperature of $28.0 \pm 2.0 \circ \mathrm{C}$ and humidity $(60$ $\pm 10 \%$ ) under $12 \mathrm{hr}$ light/dark cycles and well provided with food and water ad libitum.

All experimental protocols were performed in accordance with the guidelines for the humane use of laboratory animals established at our institution. Following acclimatization for a period of one week, procedure was started. Each animal was weighed before and at the end of the study. Weight was recorded on an electronic scale (Sartorius Precision Balance, Germany). Rats were divided into three equal groups by using random number generator. (Table-I)

1. Control group $A$

2. Experimental group B: These animals were not giving any dose after inducing gingivitis.

3. Experimental group $\mathrm{C}$ : These animals were given Eugenia jambolana extract after inducing gingivitis.

Histological changes of the buccal mucosa were studied on $3^{\text {rd }}, 4^{\text {th }}, 10^{\text {th }}$ and $20^{\text {th }}$ day after induction of gingivitis in both control and experimental group animals.

\section{Induction of Gingivitis}

For accurate examination of curing of gingivits in inflamed gingiva, moderate gingivitis was induced in rats. For this purpose, a cotton thread placed between right maxillary molars. The present study was confined to the histological and anatomical examination of 48 adult albino rats.

The animals were allotted to three groups of 16 animals each: Control group $A(I A, 2 A, 3 A, 4 A)$, Experimental group $B(1 \mathrm{~B}, 2 \mathrm{~B}, 3 \mathrm{~B}, 4 \mathrm{~B})$ was not given Eugenia Jambolana extract, while the 
Experimental group $\mathrm{C}(1 \mathrm{C}, 2 \mathrm{C}, 3 \mathrm{C}, 4 \mathrm{C})$ was given Eugenia Jambolana extract.

The rats were anesthetized with ketamine (100 $\mathrm{mg} / \mathrm{kg}$ body weight) and xylazine $(10 \mathrm{mg} / \mathrm{kg}$ body weight) by an intraperitoneal injection. ${ }^{12}$ The procedure was carried out under sterile conditions. The anesthetized animal was placed on its right side on wooden table. The area selected for inducing gingivitis was cleaned with piodine to remove saliva or any food particles that may be present. The cotton thread was placed between first and second maxillary molars of right quadrant of the group $B$ and $C$ rats for inducing gingivitis. ${ }^{13,14}$

\section{Collection of Eugenia Jambolana}

Eugenia jambolana seeds were obtained by getting fruit from University of the Punjab.

\section{Preparation of Eugenia Jambolana}

Ethanolic extract of Eugenia jambolana seeds was prepared by getting fruits of Eugenia jambolana (jamun) from University of the Punjab. Pulp was removed from the seeds and washed several times with distilled water to remove the traces of pulp; the seeds were then dried at room temperature, kernel of the seeds was separated from the seed coat, powdered in an electrical grinder and stored at $5 \stackrel{\circ}{\circ}$. Hundred gm of kernel powder was suspended in $250 \mathrm{ml}$ of distilled water and allowed it to stand overnight in refrigerator; it was then sieved through several layers of muslin cloth. The filtrate (water extract) was discarded. The residue was extracted with $95 \%$ ethanol using sox halation/ wherein ethanol was evaporated in

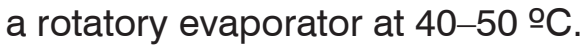

The yield of kernel was $3.2 \mathrm{~g} / 100 \mathrm{~g}$ of seed powder.

\section{Administration of Eugenia Jambolana}

The extract of Eugenia jambolana was given orally with the help of insulin syringe for 10 days.

\section{Tissue Sampling and Processing}

At $3^{\text {rd }}$ day after inducing gingivitis, four animals from each group were placed in a chloroform chamber and decapitated under deep anesthesia. (Figure-1) Rest of the animals were decapitated by the same procedure and number at $4^{\text {th }}, 10^{\text {th }}$ and $20^{\text {th }}$ day after inducing gingivitis. The whole right maxillary quadrant was dissected and after washing with saline it was fixed in neutral $10 \%$ buffered formalin for 48 hours at room temperature. Later the specimens were processed for histological slides stained with Eosin and Hematoxylin before microscopic study.

\section{RESULTS}

The general histological study of a normal gingival mucosa revealed the following layers;

1. Epithelium

2. Lamina propria

The epithelium was stratified squamous keratinized, with four basic layers. It consisted of a darkly stained layer of tall columnar cells known as stratum basale (basal layer), over which there were 7-8 strata of polyhedral cells forming the stratum spinosum (prickle layer). On top of these were 3-5 layers of flat cells forming stratum granulosum (granular layer). These layers were covered by a fine layer of anucleated corneocytes forming the stratum corneum (cornified layer). The colour of normal gingiva was pink. The normal gingival had scalloped margin. Rete ridges extending down towards the connective tissue had a usual conical shape. The lamina propria displayed fine network of collagen bundles. ${ }^{15}$ Fibroblasts and blood vessels were also present (Figure-2).

On day 3, on gross examination of the selected area in both experimental group 1B and 1C, marked redness and hypertrophy was also observed. Some ulceration also seen and there was also a tendency to bleed spontaneously. Junctional epithelium migrated apically from the cementoenamel junction and the gingival sulcus depth increased in experimental group 1B and $1 \mathrm{C}$. The color of gingiva also changed from pink to red. The texture of gingiva also affected because of inflammation. ${ }^{17}$ The inflamed gingiva was swollen and had puffy and rolled margins. The selected area of all the experimental animals was viewed under light microscope..$^{18}$ On day 3 , sign of severe gingivitis has been appeared in 
all the animals of both experimental groups $1 \mathrm{~B}$ and $1 \mathrm{C}$. It was observed that there was severe inflammation in the buccal surface of the gingival mucosa of the maxillary right quadrant. There were bundles of collagen fibers showing the evidence of fibrosis. ${ }^{19}$ There were short rete pegs. The cellular infiltrate was three times in both experimental groups as compared to normal group. ${ }^{20}$ In both experimental groups, vascular congestion was seen (Figure-3). The total count of neutrophils was $22.50 \pm 2.082$ and eosinophils was $50.00 \pm 1.414$ (Table-II) in group 1B. In group $1 \mathrm{C}$, the neutrophils count was $27.50 \pm 1.915$ and eosinophil count was $5.00 \pm 0.816$.

On day 4, the connective tissue of the two groups presented differences as well; in group$2 \mathrm{~B}$, abundance of inflammatory cells was visible in the lamina propria. Neutrophils with multilobulated nuclei were also recognized, so were a few lymphocytes accompanied by plasma cells (Figure-4). No eosinophils were seen in the connective tissue. The total count of lymphocytes was $19.75 \pm 1.708$, neutrophils was $6.50 \pm 1.219$ and macrophages was $3.25 \pm 1.258$ (Table-III). The epithelium breaks, short rete pegs also seen. Fibrosis was three times more in group $2 \mathrm{~A}$ (given no dose) as compared to group $2 \mathrm{C}$ (given Eugenia /jambolana dose).

In group 2C, long rete pegs were seen as compared to group $2 \mathrm{~B}$. In group $2 \mathrm{C}$, fibrosis was near to normal. In group $2 \mathrm{C}$, lymphocytes and macrophages were present and very few neutrophils were also seen. Some fibroblast nuclei were seen. In group $2 \mathrm{C}$, no eosinophils were seen. The lymphocytes count was $9.00 \pm 1.155$, neutrophil count was $4.00 \pm 1.414$ and macrophage count was $1.25 \pm 0.050$. The difference between inflammatory cell count between the two groups was statistically significant $(p<0.005$ Table-III).

On day 10, There was evidence of very less cellular infiltrate in group 3B. There was no vascular congestion. Numerous small capillaries can be seen beneath the regenerating epithelium. Lymphocytes, plasma cells, macrophages and few neutrophils were seen. The connective tissue of group3 B showed evidence of macrophages with large nucleus $3.25 \pm 0.95$ lymphocytes $1.25 \pm 0.500$ and few neutrophils $1.00 \pm 0.000$ were also present. The granulation tissue also contained fibroblasts forming collagen fibers. No eosinophils were present.

In contrast to which group 3C, Inflammatory cells clear out with very minimal cells still visible in the connective tissue. The group $3 \mathrm{C}$ showed less inflammatory cells (Table-IV) beneath the epithelium. The subepithelial tissue consisted of more lymphocytes $1.75 \pm 0.500$ and neutrophils $1.25 \pm 0.500$. The difference in values of a number of inflammatory cells in the two groups was statistically significant.

On day 20, Normal stratification of cells was visible. Collagen bundles were seen in the connective tissue. Healthy mucosa was seen in both experimental groups. Rete ridges goes up towards the cornifium layer. Connective tissue showed fibroblasts, loosely arraneged collagen fibres were present. There was slight evidence of collagen bundle formation too. There was evidence of very few lymphocytes $1.75 \pm 0.500$ and neutrophils $1.50 \pm 0.577$ in experimental group 4B. In group 4C, lymphocytes $1.75 \pm 0.500$ and neutrophils $1.50 \pm 0.577$ were present (Table-V). There were no evidence of macrophages and eosinophils in group $4 \mathrm{~B}$ and $4 \mathrm{C}$.

\begin{tabular}{|c|c|c|c|}
\hline Groups & $\begin{array}{l}\text { Sub } \\
\text { Groups }\end{array}$ & $\begin{array}{c}\text { Number } \\
\text { of } \\
\text { Animals }\end{array}$ & Remarks \\
\hline \multirow{4}{*}{$\begin{array}{l}\text { Control group } \\
\text { A }\end{array}$} & 1A (day3) & 4 & \multirow{4}{*}{$\begin{array}{l}\text { Without } \\
\text { given any } \\
\text { dose }\end{array}$} \\
\hline & 2A (day4) & 4 & \\
\hline & $3 A($ day10) & 4 & \\
\hline & 4A (day 20) & 4 & \\
\hline \multirow{4}{*}{$\begin{array}{l}\text { Experimental } \\
\text { group B }\end{array}$} & 1B (day3) & 4 & \multirow{4}{*}{$\begin{array}{l}\text { Without } \\
\text { Eugenia } \\
\text { jambolana } \\
\text { extract }\end{array}$} \\
\hline & 2B (day4) & 4 & \\
\hline & 3B (day10) & 4 & \\
\hline & 4B (day 20) & 4 & \\
\hline \multirow{4}{*}{$\begin{array}{l}\text { Experimental } \\
\text { group C }\end{array}$} & $1 \mathrm{C}$ (day3) & 4 & \multirow{4}{*}{$\begin{array}{l}\text { With } \\
\text { Eugenia } \\
\text { jambolana } \\
\text { extract }\end{array}$} \\
\hline & 2C (day4) & 4 & \\
\hline & $3 C$ (day10) & 4 & \\
\hline & 4D (day20) & 4 & \\
\hline
\end{tabular}

Table-I. Details of study groups 


\begin{tabular}{|c|c|c|c|c|c|}
\hline Parameter & $\begin{array}{l}\text { Control Group } \\
\text { (mean } \pm \text { S.D) }\end{array}$ & $\begin{array}{c}\text { Experimental } \\
\text { group } 1 \\
\text { (mean } \pm \text { S.D) }\end{array}$ & $\begin{array}{c}\text { Experimental } \\
\text { group } 2 \\
\text { (mean } \pm \text { S.D) }\end{array}$ & $\begin{array}{c}\text { Number of } \\
\text { Animals } \\
\text { (N) }\end{array}$ & P-Value \\
\hline Number of lymphocytes & $1.75 \pm 0.500$ & $0.00 \pm 0.000$ & $0.00 \pm 0.000$ & 4 & $<0.001$ \\
\hline Number of neutrophils & $1.25 \pm 0.500$ & $22.50 \pm 2.082$ & $27.50 \pm 1.915$ & 4 & $<0.001$ \\
\hline Number of macrophages & $0.00 \pm 0.000$ & $0.00 \pm 0.000$ & $0.00 \pm 0.00$ & 4 & \\
\hline
\end{tabular}

Table-II. Comparison of number and types of inflammatory cells between three groups on Day-3

\begin{tabular}{|c|c|c|c|c|c|}
\hline Parameter & $\begin{array}{l}\text { Control Group } \\
\text { (mean } \pm \text { S.D) }\end{array}$ & $\begin{array}{c}\text { Experimental } \\
\text { group } 1 \\
\text { (mean } \pm \text { S.D) }\end{array}$ & $\begin{array}{c}\text { Experimental } \\
\text { group } 2 \\
\text { (mean } \pm \text { S.D) }\end{array}$ & $\begin{array}{l}\text { Number of } \\
\text { Animals } \\
\text { (N) }\end{array}$ & P-Value \\
\hline Number of neutrophils & $1.25 \pm 0.500$ & $6.50 \pm 1.291$ & $4.00 \pm 1.414$ & 4 & $<0.001$ \\
\hline Number of macrophages & $0.00 \pm 0.000$ & $3.25 \pm 1.258$ & $1.25 \pm 05.00$ & 4 & $<0.001$ \\
\hline
\end{tabular}

Table-III. Comparison of number and types of inflammatory cells between three groups on Day-4

\begin{tabular}{|c|c|c|c|c|c|}
\hline Parameter & $\begin{array}{l}\text { Control Group } \\
\text { (mean } \pm \text { S.D) }\end{array}$ & $\begin{array}{c}\text { Experimental } \\
\text { group } 1 \\
\text { (mean } \pm \text { S.D) }\end{array}$ & $\begin{array}{c}\text { Experimental } \\
\text { group } 2 \\
\text { (mean } \pm \text { S.D) }\end{array}$ & $\begin{array}{l}\text { Number of } \\
\text { Animals } \\
\text { (N) }\end{array}$ & P-Value \\
\hline Number of neutrophils & $1.25 \pm 0.500$ & $1.00 \pm 0.000$ & $1.25 \pm 0.500$ & 4 & $<0.001$ \\
\hline Number of macrophages & $0.00 \pm 0.000$ & $3.25 \pm 0.957$ & $0.00 \pm 0.000$ & 4 & $<0.001$ \\
\hline
\end{tabular}

Table-IV. Comparison of number and types of inflammatory cells between three groups on Day-10

\begin{tabular}{|l|c|c|c|c|c|}
\hline \multicolumn{1}{|c|}{ Parameter } & $\begin{array}{c}\text { Control Group } \\
\text { (mean } \pm \text { S.D) }\end{array}$ & $\begin{array}{c}\text { Experimental } \\
\text { group 1 } \\
\text { (mean } \pm \text { S.D) }\end{array}$ & $\begin{array}{c}\text { Experimental } \\
\text { group 2 }\end{array}$ & $\begin{array}{c}\text { Number of } \\
\text { (mean } \pm \text { S.D) }\end{array}$ & $\begin{array}{c}\text { Animals } \\
\text { (N) }\end{array}$ \\
\hline Number of lymphocytes & $1.75 \pm 0.500$ & $1.75 \pm 0.500$ & $1.75 \pm 0.500$ & 4 \\
\hline Number of neutrophils & $1.25 \pm 0.500$ & $1.50 \pm 0.577$ & $1.50 \pm 0.577$ & 4 \\
\hline Number of macrophages & $0.00 \pm 0.000$ & $0.00 \pm 0.000$ & $0.00 \pm 0.000$ & $<0.001$ \\
\hline Number of eosinophils & $0.00 \pm 0.000$ & $0.00 \pm 0.000$ & $0.00 \pm 0.000$ & 4 \\
\hline
\end{tabular}

Table-V. Comparison of number and types of inflammatory cells between three groups on Day-20

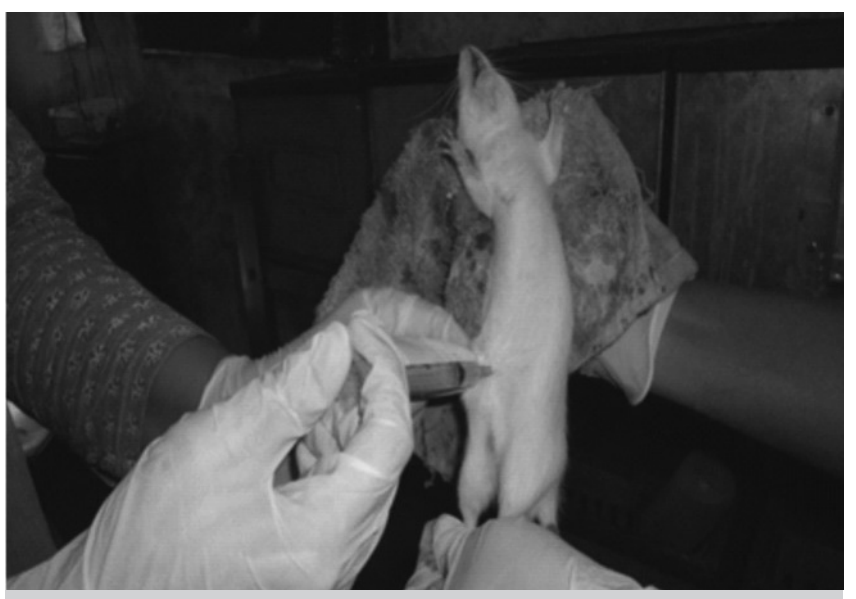

Figure-1. Photograph showing anesthetization of experimental rat by an intraperitoneal injection

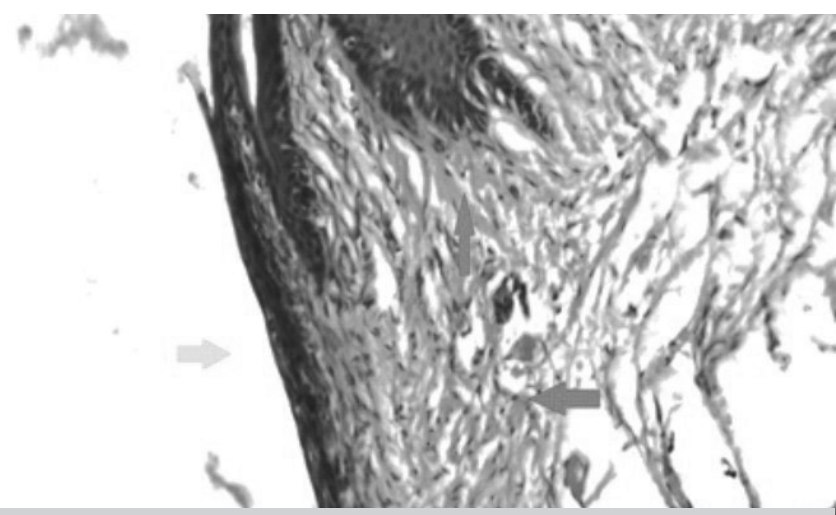

Figure-2. Section of right gingival mucosa of group-1 A on post gingival day-3 showing keratinized epithelium (black arrow), nonkeratinized epithelium (yellow arrow) rete pegs (green arrow). The lamina propria contains fibroblasts (F), collagen fibers (C), blood vessels (BV) and inflammatory cells (L) (blue arrow). H \& E stain. Photomicrograph approx. 200X. 


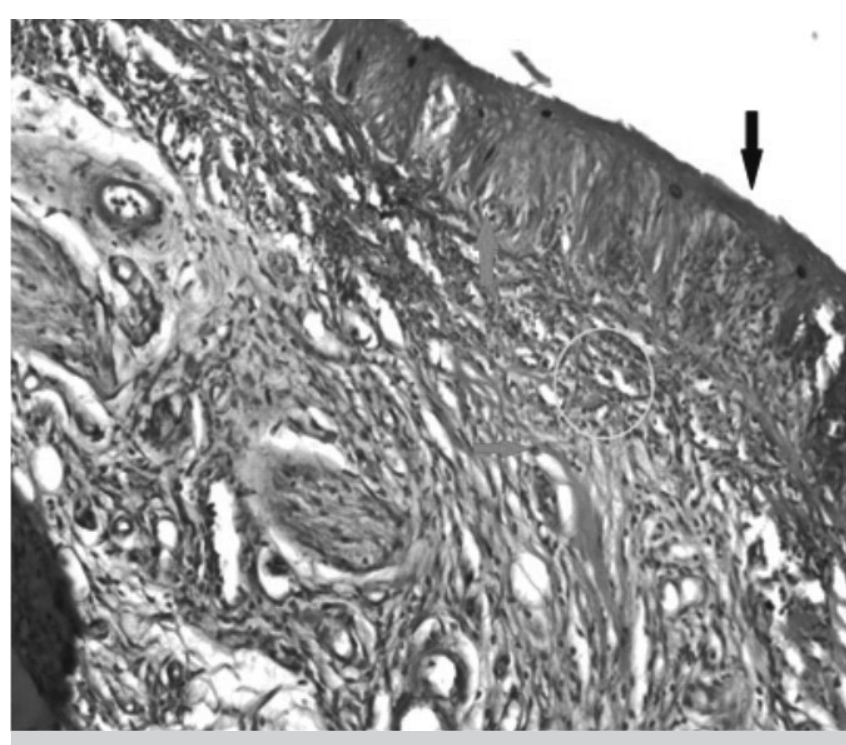

Figure-3. Section of right gingival mucosa of group-1 B on post gingival day-3 showing keratinized epithelium (black arrow), rete pegs (green arrow). The lamina propria contains fibroblasts $(F)$, collagen fibers (C), blood vessels (BV) and inflammatory cells (L) (blue arrow). The area in yellow circle shown in the next picture. H \& E stain. Photomicrograph approx. 200X.

\section{DISCUSSION}

Current study presents an account of the effects of Eugenia jambolana extract on experimentallyinduced gingivitis in albino rats. Histological evaluation was performed on the three groups $A, B$ and $C$ of albino rats on post gingivitis days $3,4,10$ and 20. The group A was control group which showed normal histology and other two groups were experimental groups i.e., Group B (giving the food and water) and group $\mathrm{C}$ (giving Eugenia jambolana extract). The results showed remarkable differences between the healing pattern of the two experimental groups B and C. In the present study, cotton thread was placed between the first and second molars of the right maxillary quadrant of the albino rats to induce the lesion of interest - gingivitis, in both experimental groups B and $\mathrm{C}$. The cotton thread acted as an irritant and caused gingival inflammatory reaction composed of leukocyte infiltration to the gingival mucosa through chemotaxis and increased vascular permeability. According to a recent study ${ }^{14}$, gingivitis was induced by placing cotton thread at the level of gingival crevice between $1^{\text {st }}$ and $2^{\text {nd }}$ molars of albino rats. In one of study, gingivitis was induced in maxillary molars of

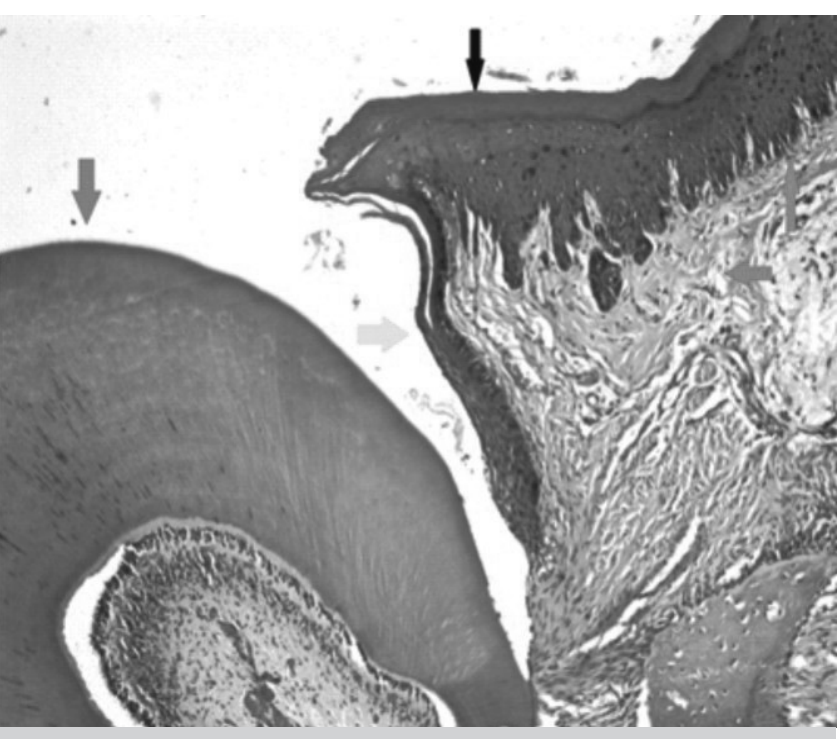

Figure-4. Section of right gingival mucosa of group-2 A on post gingival day-4 showing keratinized epithelium (black arrow), nonkeratinized epithelium (yellow arrow) rete pegs (green arrow), tooth (purple arrow). The lamina propria contains fibroblasts $(F)$, collagen fibers (C), blood vessels (BV) and inflammatory cells (L) (blue arrow). H \& E stain. Photomicrograph approx. 200X.

albino rats by using cotton thread between $1^{\text {st }}$ and $2^{\text {nd }}$ molars. Inflammation occurred because the thread acted as a foreign object which caused irritation.

In current study, on day-0, the gingivitis was observed on the buccal surface of the gingival mucosa of the first right maxillary molar. On day3 , the gingiva became inflamed. According to the study conducted by Steenbergen, (2006), gingivitis was induced after 4 days of giving injection of irritant to the mice. In the present study, the sign of gingivitis appeared after 3days of placing cotton thread. The inflamed gingiva was red in colour. After inducing gingivitis, the gingiva became swollen. There were rolled margin of the inflamed gingiva instead of scalloped margin which was present in healthy gingiva. There was bleeding when probing was done with the periodontal probe. A study ${ }^{15}$ stressed on the fact that during gingivitis, the colour of the gingiva was changed from pink to red $^{16}$ In one of the recent study ${ }^{17}$, the same gingival findings were found. The texture of the gingiva was also affected. The gingiva became swollen because of inflammation. Alterations occurred in the vascular 
network and many capillaries bed opened. There was increased exudation of GCF and proteins in the gingival plexus. Because of this increased exudation, tissue made edematous and swollen. ${ }^{18}$ Bleeding occurred during probing and brushing because of moderate gingivitis. ${ }^{19}$ Researchers consider that bleeding on probing is the result of an inflammatory reaction in the tissues surrounding the epithelial junction, and it was an objective sign of incipient periodontal changes. ${ }^{20}$

Microscopic examination reveals that the inflammatory cells mainly consisted of neutrophils and eosinophils were present. The inflammatory cells played important role in inflammation. The inflammatory cells neutrophils, lymphocytes and monocytes were found in the gingiva. There was increased number of leukocytes in inflamed gingiva.

Many changes occurred in the periodontal tissue during the pathogenesis of inflammation. Gingival overgrowth was accelerated by plaque accumulation. Many events occurred, due to the attachment of pathogens on the gingival tissue disturbing connective tissue homeostasis and alveolar bone starts destroying. The most distinct feature of gingival overgrowth was inflamed and swollen gums (free gingival margin and interdental papilla became enlarged and thickened gradually covering crown of the tooth). Gingival overgrowth can be idiopathic, inherited, also associated with other systemic diseases (such as renal or hepatic diseases). It was believed that all gingival lesions connective tissues became more fibrotic, with varying degree of inflammation and increase in size occurred gingival epithelium. The dose, duration and identification of the drug were main factors affecting degree of inflammation, cell sample and fibrosis.

On day-4, group 2B rats showed the signs of acute gingivitis. Lymphoctyes and macrophages dominated the inflammatory infiltrate developed in the gingival connective tissues. Neutrophils were also present in this infiltrate, although most of the neutrophils move from gingival epithelium and connective tissues, established a relationship with plaque. Lymphocytes and macrophages accelerated fibrosis by the releasing chemotactic factors. These factors recruited fibroblast to the site of inflammation, produced FGF which activates the fibroblasts, results in fibrosis to replaced lost collagen.

In contrast to this, in group $2 \mathrm{C}$, the inflammatory cells count was also less than group 2B because of the anti-inflammatory property of Eugenia jambolana. The inflammatory cell infiltrate mainly consisted of neutrophils, lymphocytes and macrophages. The leaf extract of Eugenia jambolana was rich in flavonoids. The antiinflammatory activity of Eugenia jambolana had been correlated with the methanolic leaf extract of Eugenia jambos, a closely related species containing same flavonoids present in Eugenia jambolana. Researchers showed that some isolated flavonoids and catechins were possessing anti-inflammatory, anti-allergic and analgesic activities. On the other hand, crude extracts of Eugenia jambolana administered orally in rats, showed gastro protective and antiulcerogenic property due to the presence of tannins. However, Eugenia jambolana leaves or flowers contained few known flavonoids.

On day-10, the inflammatory cells count was also less as compared to the inflammatory cell count of day 4. Histology of lamina propria and epithelium of the gingiva disturbed. On day 10 , lymphocytes, neutrophils and macrophages were also present. According to one of the recent study $^{21}$, in all gingival lesions, extensive fibrosis occurred in connective tissue which became enlarged with varying degrees of inflammation and inflamed gingival epithelium. Immediately after plaque deposition started to the gingival margin, subjacent connective tissue became infiltrated with inflammatory cells and initiate its destruction. At the same time, tissue repair occurred, showing fibrosis at the site of inflammation. The sequence of events in the development of periodontal diseases were the severities of inflammation, tissue destruction and healing.

Inflammatory cells such as lymphocytes and macrophages played an important role in 
inflamed gingiva. Cytokines and growth factors were mainly released by macrophages and lymphocytes. ${ }^{21}$

In contrast to group $3 \mathrm{~B}$, the group $3 \mathrm{C}$ the inflammatory cell count was low. The group $3 \mathrm{C}$ showed almost complete healing at day 10.

On day-20, the group 4B showed complete healing. Lymphocytes and neutrophils were present. Gingival tissues had a capability of repair, regeneration, renewal and healing after inflammation and wounding. This regeneration ability of the gingival epithelium was necessary for maintaining homeostasis in the gingival mucosa. Lamina propria also healed very rapidly after inflammation due to this regeneration ability. Researchers showed interest in the natural processes which control periodontal tissues response to wounding, and how cellular interaction occurred between different periodontal tissues.

In contrast to this, the group $4 \mathrm{C}$ also showed complete healing. Microscopic examination revealed normal histology. The cell count was normal consisting mainly of lymphocytes and neutrophils. In the present study, gingivitis was treated with the ethanolic extract of Eugenia jambolana. The extract of Eugenia jambolana was given orally to albino rats for 10 days with 1 week follow up. The extract of Eugenia jambolana reduced inflammation morequickly in experimental group $C$ as compared to experimental group B. In one of study conducted in Bangladesh. ${ }^{22}$ people lived in villages were unaware about taking care for their eye and teeth. So that majority of the rural people who were suffering from dental problems mainly swollen gums, toothache, dental caries, hallitoses, gingivitis etc and eye problems like conjunctivitis. For treating oral diseases, one kaviraj (people living in village) used the paste formed by crushing the roots of Eugenia jambolana. The powder formed by crushing roots of Mangifera indica in combination with the roots of Areca catechu and Aegle marmelos. This mixture was added in the Eugenia jambolana paste. This paste was applied for treating tooth problem like gingivitis and helitosis.
Rural people of the Bahraich district are socioeconomically very poor so these uneducated poor people were completely dependent on the previous knowledge of herbal medicines for the treatment of different ailments. These people were known the medicinal importance of these herbal plants because of the knowledge transferred from their forefathers. The rural people of Bahraich chewed two leaves of Eugenia jambolana daily to treat gingivitis. The leaves of Eugenia jambolana had anti-inflammatory effect so that gingivitis heals rapidly.

\section{CONCLUSION}

The Eugenia jambolana is a cheap fruit and is part of everyday life in lower socioeconomic class. Their effects on diabetes, odema, inflammation, constipation, bloody stools and liver inflammation were known, but not enough evidence was available to determine its effects on gingivits. This study proved its beneficial effects on the healing of gingivits. There was a marked difference in the healing pattern between the two groups. In the Eugenia jambolana extract group, there was marked acceleration in the healing pattern, epithelium regenerated more rapidly, inflammatory cell count were low and sulcus depth were within normal range at the end of the experiment with a subsequent rapid healing. Oral intake of Eugenia jambolana can heal gingivitis rapidly. The contents in Eugenia jambolana have an anti-inflammatory action on the soft tissue. Results suggest that epithelial changes seen in the experimental group-C could be a result of constant healing caused by the anti-inflammatory nature of Eugenia jambolana. Eugenia jambolana extract must be used for oral problems, especially in case of gingivitis.

Copyright $\subseteq 25$ June, 2019.

\section{REFERENCES}

1. Squier C, brogden K. Human oral mucosa: Development, structure and function. John Wiley \& Sons; 2010Dec 29.

2. Solanki G. A general overview of periodontal pockets. International Journal of Biomedical Research. 2012 Apr 1; 3(3):127-30. 
3. Lindhe J, Meyle J. Periimplantdiseases: Consensus report of the sixth European workshop on periodontolgy. 2008 Sep 1; 35(s8):282-5.

4. Moon WJ, Choi SY, Chung EC, Kwon KH, Chae SW. Peripheral ossifying fibroma in the oral cavity: CT and MR findings. Dentomaxillofacial Radiology. 2014 Jan 28.

5. Bulut S, Uslu H, Ozdemir BH, Bulut OE. Analysis of proliferative activity in oral gingival epithelium in immunosuppressive medication induced gingival overgrowth. Head and face medicine. 2006 May 19; $2(1): 1$.

6. Payne W, Page RC, Ogilvie A, Hall W. Histopathologic features of the initial and early stages of experimental gingivitis in man. Journal of periodontal research. 1975 Apr 1; 10(2):51-64.

7. Soames JV, Davies RM. Intracellular collagen fibrils in early gingivitis in the pathogenesis of periodontal disease. Journal of periodontal research, [Online]. Available at: http://www.d.o.i.: 10.1111/j.16000765.1991.tb01649.x.

8. Lang NP, Schatzle MA, Loe H. Gingivitis as a risk factor in periodontal disease. Journal of clinical Periodontology. 2009 Jul 1; 369s10):3-8.

9. Jain Y. Clinical evaluation of $\mathbf{0 . 2} \%$ hyaluronic acid containing gel in the treatment of gingivitis. Medical Journal of Dr. DY Patil University. 2013 Oct 1; 6(4):416.

10. Roy A, Bhattacharya S, Pandey JN, Biswas M. Antiinflammatory activity of Syzygium cumini leaf against experimentally induced acute and chronic inflammations in rodents. Alternative medicine studies. 2011 Jul 15; 1(1):6.

11. Benherlal PS, Arumughan C. Chemical composition and in vitro antioxidant studies on Syzygium cumini fruit. Journal of the Science of Food and Agriculture. 2007 Nov. 1 ; 87(14):2560-9.

12. Pennstate, 2013. Injectable anesthesia, Animal resource program, [online]. Available at $<$ http:// www.research.psu.edu/arp/anesthesia/injectableanesthesia>.
13. Kraivaphan $P$, Amornchat $C$. Effect of an essential oil-containing dentifrice on established plaque and gingivitis. Southeast Asian J Trop Med Public Health, 2012 43(1):243-48.

14. Okuda K, Takazoe I. The role of Bacteroides gingivitis in periodontal disease. Advance in dental research. 1988 Nov $1 ; 2(2): 260-8$.

15. Kim YS, Chung $\mathrm{CH}$, Lim SB. Gingival color change after scaling \& sybgingival root planning. The Journal of the Korean Academy of Periodontolgy. 2001 Sep 1; 31(3):501-11.

16. Raber Durlacher JE, Steenbergen TV, Velden UV, Graaff JD, Abraham Inpijn. Experimental gingivitis during pregnancy and postpartum: Clinical, endocrinological, and microbiological aspects. Journal of clinical periodontology. 1994 Sep 1; $21(8): 549-58$.

17. Ifesanya JU, Oke GA. Self report of adverse gingival conditions among pregnant South-Western Nigerian women. Journal of Dentistry and Oral Hygiene. 2013 Feb 28; 5(2); 13-20.

18. Lindhe, J., Lang, N.P. and Karring, T., 2009. Clinical Periodontology and implant dentistry. $5^{\text {th }}$ edition. Blackwell Munksgaard.

19. Amoian B, Moghadamnia AA, Barzi S, Sheykholeslami S, Rangiani A. Salvadora persica extract chewing gums and gingival health: Improvement of gingival and probe-bleeding index. Complementary therapies in clinical practice. 2010 Aug 31; 16(3):121-3.

20. Lages EM, Marcos B, Pordeus IA. Oral health of individuals with the cleft lip, cleft palate, or both. The Cleft palate-craniofacial journal. 2004 Jan; 41(1):59-63.

21. Bartold PM, Narayanan AS. Molecular and cell biology of healthy and diseased periodontal tissues. Periodontology 2000.2006 Feb 1; 40(1):29-49.

22. Zakaria DM, Islam M, Anisuzzaman sm, Kundu SK, Khan MS, Begum AA. Ethno medical survey of medical plants used by folk medical practitioners in four different of Gazipur District, Bangladesh. Advances in Natural and Applied Sciences, Bd.2011 Nov1;9. 


\begin{tabular}{|c|l|l|}
\hline \multicolumn{3}{|c|}{ AUTHORSHIP AND CONTRIBUTION DECLARATION } \\
\hline Sr. \# & \multicolumn{1}{|c|}{ Author(s) Full Name } & \multicolumn{1}{|c|}{ Contribution to the paper } \\
\hline 1 & Sana Chaudhry & Research / Original Draft. \\
2 & Amna Amanat & Data collection \\
3 & Nadia Bhutta & Discussion Review. \\
4 & M. Behzad Salahuddin & Data analysis. \\
5 & Muhammad Bilal Arshad & Critical review of article. \\
6 & Nasrullah Khan & Article composition. \\
\hline
\end{tabular}

